$\xi=-1$

\title{
Finite Element Method Analysis of Normal and Corrosion Buckling with ANSYS17 Program for Stainless Steel 304 Alloy
}

\author{
Hussain Jasim AL Akawai ${ }^{1}$, Khalid Mershid Aweed ${ }^{2}$, Shawthab Ali Jaber ${ }^{3}$ \\ ${ }^{1}$ University of Technology in Baghdad \\ ${ }^{2}$ University of Al Mustansiriya in Baghdad \\ ${ }^{3}$ University of Al Mustansiriya in Baghdad
}

\begin{abstract}
In the present research the effect of corrosion on buckling behavior of 304 stainless steel with increasing of compressive dynamic loads was studied. There are two types of the columns, long columns and intermediate columns were used. For compression test, there are 24 columns specimens were used in the dynamic axis, 12 columns tests were carried out with increasing in the dynamic axis of compressive load, while for the corrosion test was performed by using 12 specimens were buried for two months under the ground before tested them. The allowable deflection in lateral axis is $1 \%$ in the length of column. When the deflection in lateral axis reaches $1 \%$ and does not increase more than it, and when removing the applied load, the column will return back to the normal state. This is defined critical buckling of columns. To calculate the original deflection. The digital gauge was employed at the distance about 0.7 for the column length at the fixed end of column. has alarm system was used to define critical buckling and to avoid the failure of the specimen and installed at the distance equal to 0.7 of the column length from fixed end. The empirical results showed that the effect of negatively corrosion on mechanical properties of alloys with $2.53 \%$ reduction of ultimate tensile strength comparing with non corroded specimens, in the other hand the corrosion will reduce the critical buckling load by $6 \%$ for two months. The experimental results comparing with the theoretical results obtained by Perry Robertson and Euler. Johnson with the results analyzed by ANASYS17. The results of this work are agreed with Perry-Robertson and Euler- Johnson by a safety factor about $(1,3)$ and 3 respectively while the results of ANASYS showed that agreement with the calculated and measured values by safety factor about (2).
\end{abstract}

Keywords: effect of negatively corrosion, deflection in lateral axis, ANSYS17.

\section{Introduction}

Calculating the stability of structures has always been an important engineering discipline. Especially the calculation of a critical buckling force of the structure had been a subject for the study of Leonard Euler in 1744 who calculated the critical buckling load for the simply supported colume. Buckling is defined like a phenomenon as the structure will change from equilibrium state to another equilibrium state. An important factor of buckling is the defection of the loads of the structural engineering part at which the failure occurred at a critical value of the buckling load. When the buckling load reaches to the critical point, the structural part will change from stable condition to unstable condition which in turn put the people at risk state. Recently, the current industrially processing emphasizes to use structural parts with high strength and light weight to carry high loads and absorb high energy. Dynamic compressive load is applied on test rig and experimental tests were done for the ideal colume with dynamic loads, Current study will verify the miniature mechanical testing for stainless steel 304 which are used n numerous field such as industrial, commercial and domestic because of their heat resistance in many different liquids or solids equipment used for mines, enjogenic, chemical [9], then studying the buckling at elastic behavior of the column fixed by pins, then studying the effect of corrosion time on the dynamic behavior of buckling for underground column of 304 stainless steel to measuring initial deflection for 304 stainless steel column by using indictor dial digital gauge by Using laser alarm system to measure the critical deflection, and then Comparing between the experimental results with Euler, Johnson and Perry Robertson with experimental results then comparing with ANSYS 17 program.There are many investigations were published in this field such as [3] investigated the I-beam buckling under combined loads. They proposed an approach to estimate the critical buckling under different conditions of the above theory is suitable for explaine the I-beam buckling and well estimate the critical buckling load. [4] tested columns made from carbon steel without surface treatment and with carburized surface treatment at different slenderness ratio. The test results revealed that the columns of carbuized case bear high critical buckling load compared to the non-surface treatment. Ones. Also the FEM analysis was found to be in good agreement with the experimental results [5] studied the effect of slenderness ratios (S.R.) and the cross- section al areas on critical buckling behavior of steel structure columns using two end conditions, pinned-pinned and fixed-free with different sections, rectangle, circle and square using (FEM) with numerical analysis approaches. The concluded that the fixed-free column has lower buckling load than the pinned-pinned one. Sidharth (2009) [10] tested experimentally plate subjected to buckling loads and corrosion. Ot was found that pitting corrosion had significantly effect on the mechanical and buckling properties. Also It had been proposed model using FEM method to estimate the DOP (degree of corrosion pitting) on the properties of the plate. It was concluded that the DOP is the main that reduced the tensile strength and buckling load of plate. Oszyold and Dunai (2012) [11] investigated the buckling and corrosion interaction of steel 
angle profile expermenitally. They found that the corrosion reduce the croos- section area of the angle section resulted in reduction in critical buckling resistances. Causing big scatter in resistance of steel angle buckling. Kashani et al (2016) [12] studied the effect of pitting corrosive behaviour on buckling resistance of columns made from steel alloy. They developed a numerical approach to estimate the buckling corrosion interaction of columns. It was obtained that corrosion has negatively influence on the mechanical and buckling properties.

\section{Experimental Procedure}

\subsection{Material Used}

The material used in the current work is 304 stainless steel. This material is widely used in marine parts and drilling operations, coul hopper lenings, cooking equipment, Cooling cail, cryagenic Vessels, feed water tubing, dairy equipment, evaporators, flatware utensils, nuclear vessels, food processing tool, flexible metal hosepipe, hospital surgical tool, hypodermic baits, chemical requirement. 304stainless steel is a most applied of all stainless steel alloys because of the mechanical and chemical effects with fuse power and corrosion/oxidation resistance which provide the best all round showing stainless steel at relatively less cost. The material used was recived from the mechanical company (AlAscondarya) and examined to obtain the chemical analysis of the above steel alloy in state company for Engineering Rehabilitation and Inspection (SIER). The obtained results given in the table (2$1)$, while the mechanical properties were gives in table (2-2) which were obtained using a test machine WDW-200E at University of Technology-Material Engineering Department, and carried out at room temperature $\left(25^{\circ} \mathrm{C}\right)$.

Table 2-1:. The Chemical composition of 304 stainless steeL (wt \%)

\begin{tabular}{|c|c|c|c|c|c|c|c|c|c|}
\hline stainless steel 304 & $\begin{array}{c}\mathrm{C \%} \\
\text { Carbon }\end{array}$ & $\begin{array}{c}\text { Mn \% } \\
\text { Manganese }\end{array}$ & $\begin{array}{c}P \% \\
\text { Phosphorus }\end{array}$ & $\begin{array}{c}S \% \\
\text { Sulfur }\end{array}$ & $\begin{array}{c}S \boldsymbol{S i} \% \\
\text { Silicon }\end{array}$ & $\begin{array}{c}\mathrm{Cr} \% \\
\text { Chromium }\end{array}$ & $\begin{array}{c}\mathrm{Ni} \% \\
\text { Nickel }\end{array}$ & $\begin{array}{c}N \% \\
\text { Nitrogen }\end{array}$ & $\begin{array}{l}\mathrm{Fe} \\
\text { Iron }\end{array}$ \\
\hline $\begin{array}{c}\text { Standard } \\
\text { ASTM A240 } \\
{[49]}\end{array}$ & 0.08 max. & 2.00 max. & $\begin{array}{l}0.045 \\
\text { Max. }\end{array}$ & $\begin{array}{l}0.030 \\
\max .\end{array}$ & 0.75 max. & $18.0-20.0$ & $8.0-12.0$ & 0.10 max. & Balance \\
\hline Experimental & 0.062 & 1.72 & 0.016 & 0.021 & 0.66 & 18.9 & 9.6 & 0.07 & Balance \\
\hline
\end{tabular}

Table 2-2:. Mechanical properties of 304 stainless steel

\begin{tabular}{|c|c|c|c|c|c|}
\hline$(\boldsymbol{\mu})$ & $\begin{array}{c}\mathbf{G} \\
(\mathbf{G p a})\end{array}$ & $\begin{array}{c}\mathbf{E} \\
(\mathbf{G p a})\end{array}$ & $\begin{array}{c}\boldsymbol{\sigma}_{\mathbf{y}} \\
(\mathbf{M p a})\end{array}$ & $\begin{array}{c}\mathbf{\sigma}_{\mathbf{u}} \\
\mathbf{M p a})(\end{array}$ & 621 \\
\hline 0.3 & $74-77$ & $193-200$ & 290 & 628 & 304stainless steel \\
\hline 0.31 & 76 & 199 & 302 & 628 Experimental \\
\hline
\end{tabular}

\subsection{Tensile Test}

A mechanical property for 304 stainless steel is by using a (WDW-200E) tensile rig of $200 \mathrm{kN}$ full capacity which is presented in Figure (2-1). All the above properties are made in university of technology_Materials Engineering department, by using tensile test in according to the American standard (ASTM A370). The shape and dimensions of the tensile sample are shown in figure (22).

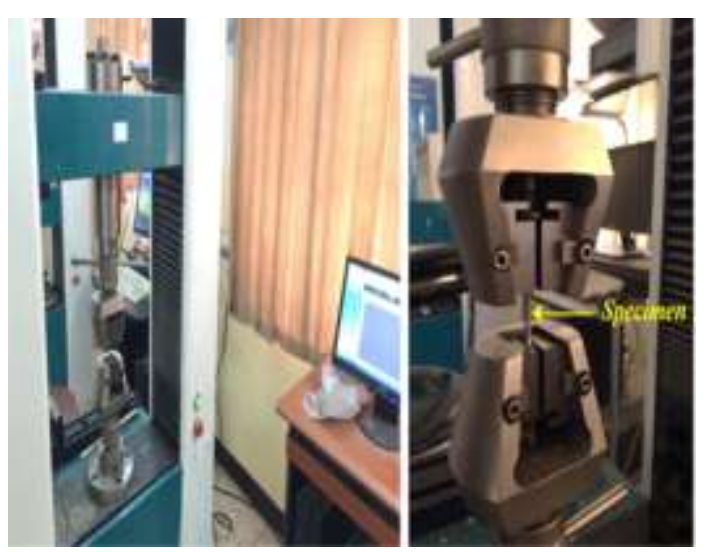

Figure 2-1. the tensile test instrument

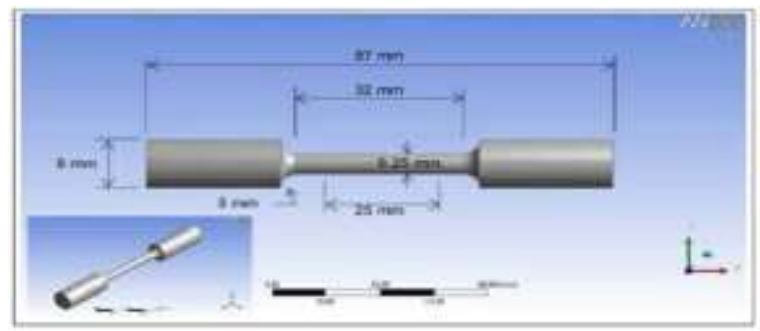

Figure 2-2. shows the specimen of tensile test

\subsection{Buckling Test}

Several ways to evaluate the fiasco of structural component such as the kind of the structural component of the force and the properties of the examined material. For ideal, the axle of the car may unexpected to break down the refined cycle of the loading. This leads the structure to lose ability to complete the intended function of it. To avoid this type of failure is done by designing the structural component to stay through the limit of high stress which can be carried. So, the stiffness and strength are the main factors for this design. In addition, the buckling is considered as a failure resulting as instability of the structural component of axial compression. One type of failure is buckling which does lead to the sudden fracture in the structural component when the column is subjected to the compressive stress. when the column of a structural component is forced with small axial compression, which it is deformed with the convert in the solid geometry [1]. At a critical rate of a load, experimentally a structural component has not large deformation and then it is unstable to carry applied load. This is mean that the occurrence of buckling. At the first, when the applied load on the column are stable. However, increasing the load more than buckling load, it being unstable, it is also mean that deviation the column will lead to the buckling. This point which that the buckling occurs, thus point is called as bifurcation point. The torsion system consists of an electrical motor of $(0.5$ $\mathrm{KW}$ ), operating at two different speeds, low speed (17 r.p.m) and high-speed (34 r.p.m) and when the electrical motor starts, it causes movement in two different directions clockwise and counterclockwise. A cycle-counter indicator (indicates the number of cycles), is fixed in the front of the control panel. The register digits are $(99999.9 \%)$, it refers to the number of cycles during the test. Figure (3-3) shows the torsion system of the test-rig machine [1]. 


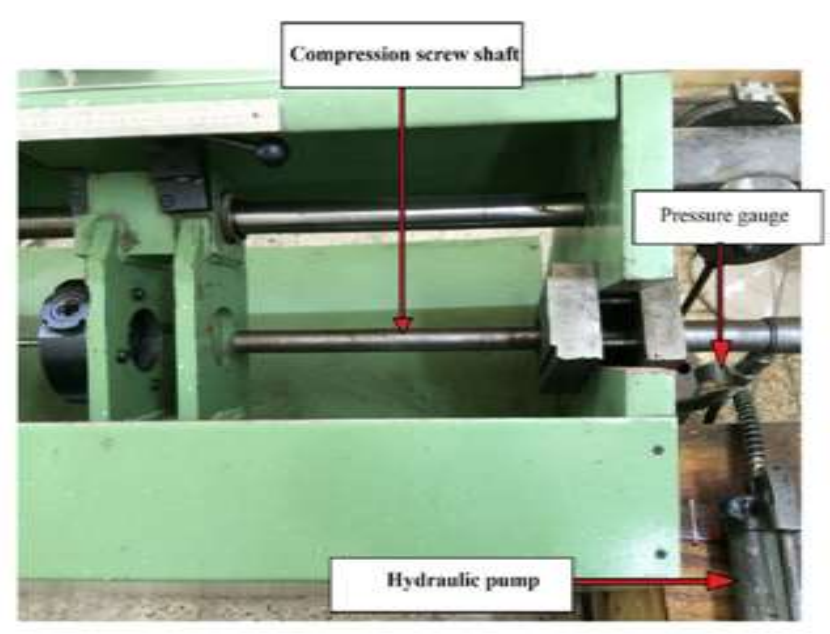

Figure 2-3. Compression machine section

\subsection{Laser System}

Laser were used in the electrical circuit of a core components considered in this system. Laser ray does go from one side to the other long distance without scattering property and a ray done almost invisible. However a radiation point and incident dot was visible. So by this security project it will be an invisible boundary of the critical area. They are 2 parts of the systems, one was transmitter and other had receiver. Where a transmitter was nominated on a electronic digital caliper device held within a Buckling test Rig's machine. A receiver section had the sensitive kind of LDR which was held within a buckling test Rig's machine, In other hand in exchange for section at a vertical and a sender to the test specimen. Then a specimen of check is installed at a test-rig's machine and located digital dial gauge indicator at a 0.7 distance of an effective length from the fixed end, where read and record initial deflection. When operated the laser alarm system for a transmitter section was nominated at an electronic digital caliper device on the distance of 0.7 from an action length of a fixed end too. So as when a laser beam comes into contact with a test specimen surface, Then raise a laser beam with a electronic Digital calipers many initial deflection plus $1 \%$ of an effective length of a test specimen, were these represents a critical buckling load. When a check start operating an electric motor with the less speed (17r.p.m), an axial dynamic squeeze pressure was gradually applied under a load control at a specimen by a hydraulic pump of compression method. When the number lateral buckling deflection reaches to a laser system beam level, A test specimen get switch off a laser beam track, and here begin an electrical method working out of the sound buzzer to alert that a test specimen have reached a number of the sensitively lateral buckling deflection, that generated with a critical buckling load, then an electrical motor do switched-off handle.

\section{Results and Discussion}

In this work 12 Specimens had checked under rising a Compressive Dynamic loading. Machines have unique 2 speeds (17r.p.m)

$\sigma=\left[\frac{\sigma_{y}+(1+\eta) \sigma_{e}}{2}-\sqrt{\left(\frac{\sigma_{y}+(1+\eta) \sigma_{e}}{2}\right)^{2}-\sigma_{y} \sigma_{e}}\right]$ and (34r.p.m.). The velocity of (17r.p.m.) had taken care because a Buckling phenomenon was not obvious in high speeds, however is uncontrollable besides a designing lives have not be controlled. These Specimens have been intended by different slenderness ratios, for checking under increasing forces where Table (4-1)

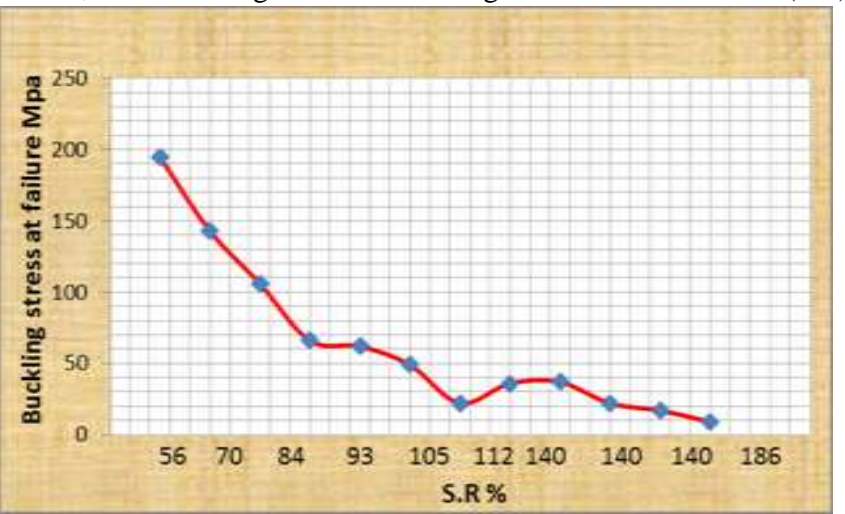

shows the results for the specimens were checked under increasing compressive dynamic compressive forces for long columns (304 stainless steel alloys). The conditions of equilibrium may be shown experimentally by loading a long column in a standard testing machine, The column remains straight until the load reaching to critical values but the material deflection increases if the elastic limit or yield stress is not exceeded and the column returns to its initial shape, when the load is removed. Figure (3-1) give the relation between buckling load and S.R. showing that increasing S.R. resulted in reducing the buckling stress. In other hand, considering the changing of the cross-section leading to reduced the buckling load compared to the normal columns for buckling test.

Table 3-1:. The results of the specimens tested under increasing compressive dynamic loads for long columns (304 stainless steel alloy)

\begin{tabular}{|c|c|c|c|c|c|c|c|c|}
\hline $\begin{array}{c}\text { Sp. } \\
\text { NO. }\end{array}$ & $\begin{array}{c}\mathbf{L} \\
\mathbf{m m}\end{array}$ & $\begin{array}{c}\text { Leff } \\
\mathbf{m m}\end{array}$ & $\begin{array}{c}\mathbf{D} \\
\mathbf{m m}\end{array}$ & $\begin{array}{c}\mathbf{A} \\
\mathbf{m m}^{\mathbf{2}}\end{array}$ & $\mathbf{S . R}$ & $\begin{array}{c}\mathbf{P c r} \\
\mathbf{N}\end{array}$ & $\begin{array}{c}\boldsymbol{\delta} \mathbf{i n} \\
\mathbf{m m}\end{array}$ & $\begin{array}{c}\boldsymbol{\delta} \mathbf{\mathbf { m }} \\
\mathbf{1 \%} \\
\mathbf{o f ~ L}\end{array}$ \\
\hline $\mathbf{1}$ & 400 & 280 & 8 & 50.25 & 140 & 1864 & 0.36 & 4 \\
\hline $\mathbf{2}$ & 400 & 280 & 6 & 28.26 & 186.6 & 361 & 0.63 & 4 \\
\hline $\mathbf{3}$ & 400 & 280 & 4 & 12.5 & 280 & 114 & 0.51 & 4 \\
\hline $\mathbf{4}$ & 300 & 210 & 6 & 28.26 & 140 & 658 & 0.71 & 3 \\
\hline $\mathbf{5}$ & 300 & 210 & 4 & 12.5 & 210 & 211 & 0.49 & 3 \\
\hline $\mathbf{6}$ & 200 & 140 & 4 & 12.5 & 140 & 458 & 0.84 & 2 \\
\hline
\end{tabular}

Figure 3-1:. Dynamic compression buckling stress for (304 stainless steel alloy) columns

\subsection{The Perry- Robertson Theory and Its Applications}

Table (3-2) illustrates the applications of P.R. formula compared to the experimental results. It is indicated that the direct application of P.R. resulted in satisfactory prediction of buckling load under dynamic increasing satuiation. But if taking 1.3 safety factor for buckling results leads to underestimate the P.R. results showing satisfactory estimation 
Table 3-2:. Comparison between Perry-Robertson results with experimental critical load value for long columns

\begin{tabular}{|c|c|c|c|c|c|c|c|c|}
\hline \multirow[t]{2}{*}{$\begin{array}{l}\text { Sp } \\
\text { No }\end{array}$} & \multirow{2}{*}{$\begin{array}{c}\mathbf{L} \\
\mathrm{mm}\end{array}$} & \multirow{2}{*}{$\begin{array}{c}\text { D } \\
\mathrm{mm}\end{array}$} & \multicolumn{2}{|c|}{$\boldsymbol{P}_{\mathbf{E X P}}$} & \multicolumn{2}{|c|}{$P_{\operatorname{cr}(\mathrm{N})}^{P_{\text {Perry-Robertson }}}$} & \multicolumn{2}{|c|}{$P_{\operatorname{cr}^{(\mathrm{N})}} \underbrace{}_{\text {of } 1.3}$} \\
\hline & & & $\begin{array}{c}\text { As- } \\
\text { received }\end{array}$ & $\begin{array}{c}60 \\
\text { days }\end{array}$ & $\begin{array}{c}\text { As- } \\
\text { received }\end{array}$ & $\begin{array}{c}60 \\
\text { days }\end{array}$ & $\begin{array}{c}\text { As- } \\
\text { received }\end{array}$ & $\begin{array}{c}60 \\
\text { days }\end{array}$ \\
\hline 1 & 400 & 8 & 1864 & 1787 & 2237 & 2165 & 1721 & 1665 \\
\hline 2 & 400 & 6 & 361 & 342 & 427 & 415 & 328 & 319 \\
\hline 3 & 400 & 4 & 114 & 110 & 140 & 136 & 108 & 105 \\
\hline 5 & 300 & 4 & 211 & 202 & 248 & 242 & 191 & 186 \\
\hline 6 & 200 & 4 & 458 & 443 & 550 & 539 & 423 & 415 \\
\hline
\end{tabular}

Euler detour for 304 stainless steel alloy associate with a yield

\subsection{Uses of Johnson and Euler Formulas to Experi-} mental facts

These Johnson's and Euler's theories could use to estimate of sensitive buckling strength, and which has baneful in an early stage of a design process. That study does divide members into an intermediate and long column, where Johnson's equation was good for an intermediate length while equation of Euler is good for long members. A tangent point together Johnson detour at strength at $300 \mathrm{Mpa}$ with S.R. $=112$. Intermediate columns were defined with a minimum slenderness ratio other hand, 304 stainless steel alloy, the rate was equal S.R. $=52$ together known as long members, i.e. Euler equation has use but should be noted that it was also proof area's Johnson. Johnson's equation estimates the critical buckling stress for a test sections to be less than a sensitively buckling sterngth rated with an equation of Euler. The estimation of Pcr according to above theories can be listed in tables (3-3) and (3-4).

Table 3-3:. Comparison between Euler results with experimental critical load value for long columns

\begin{tabular}{|c|c|c|c|c|c|c|c|c|}
\hline \multirow[t]{2}{*}{$\begin{array}{l}\text { Sp. } \\
\text { No. }\end{array}$} & \multirow{2}{*}{$\begin{array}{l}\mathbf{L} \\
\mathrm{mm}\end{array}$} & \multirow{2}{*}{$\begin{array}{l}\text { D } \\
\mathrm{mm}\end{array}$} & \multicolumn{2}{|l|}{$\begin{array}{l}P_{\operatorname{cr}}(\mathrm{N}) \\
\text { Exp. }\end{array}$} & \multicolumn{2}{|l|}{$\begin{array}{l}P_{\text {Cr }}(\mathrm{N}) \\
\text { Euler }\end{array}$} & \multicolumn{2}{|c|}{$\begin{array}{l}P_{\operatorname{cr}(\mathrm{N})} \\
\text { Euler with S.F } \\
\text { of } 3\end{array}$} \\
\hline & & & $\begin{array}{l}\text { AS- } \\
\text { received }\end{array}$ & $\begin{array}{l}60 \\
\text { days }\end{array}$ & $\begin{array}{l}\text { AS- } \\
\text { received }\end{array}$ & $\begin{array}{l}60 \\
\text { days }\end{array}$ & $\begin{array}{l}\text { AS- } \\
\text { received }\end{array}$ & $\begin{array}{l}60 \\
\text { days }\end{array}$ \\
\hline 1 & 400 & 8 & 1864 & 1787 & 5072 & 4899 & 1690 & 1633 \\
\hline 3 & 400 & 4 & 114 & 110 & 361 & 306 & 120 & 102 \\
\hline 4 & 300 & 6 & 658 & 618 & 2826 & 2730 & 942 & 910 \\
\hline 5 & 300 & 4 & 211 & 202 & 560 & 544 & 186 & 181 \\
\hline 6 & 200 & 4 & 458 & 443 & 1261 & 1241 & 420 & 413 \\
\hline
\end{tabular}

Table 3-4:. Comparison between Johnson Formula results with experimental critical load value for intermediate columns

\begin{tabular}{|c|c|c|c|c|c|c|c|c|}
\hline \multirow[t]{2}{*}{$\begin{array}{l}\text { Sp. } \\
\text { No. }\end{array}$} & \multirow{2}{*}{$\begin{array}{l}\mathbf{L} \\
\mathrm{mm}\end{array}$} & \multirow{2}{*}{$\begin{array}{l}\text { D } \\
\mathrm{mm}\end{array}$} & \multicolumn{2}{|c|}{$P_{\text {Exp. }}(N)$} & \multicolumn{2}{|l|}{ 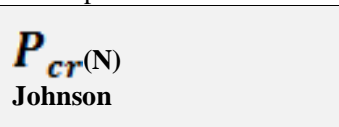 } & \multicolumn{2}{|c|}{$\begin{array}{l}P_{\operatorname{cr}(\mathrm{N})} \\
\text { Johnson with S.F } \\
\text { of } 3\end{array}$} \\
\hline & & & $\begin{array}{l}\text { AS- } \\
\text { received }\end{array}$ & $\begin{array}{l}60 \\
\text { days }\end{array}$ & $\begin{array}{l}\text { AS- } \\
\text { received }\end{array}$ & $\begin{array}{l}60 \\
\text { days }\end{array}$ & $\begin{array}{l}\text { AS- } \\
\text { received }\end{array}$ & $\begin{array}{l}60 \\
\text { days }\end{array}$ \\
\hline 1 & 400 & 10 & 4836 & 4716 & 12330 & 11906 & 4110 & 3968 \\
\hline 2 & 300 & 10 & 8277 & 8127 & 17126 & 16423 & 5708 & 5474 \\
\hline 3 & 300 & 8 & 3305 & 3185 & 8716 & 8433 & 2905 & 2811 \\
\hline 5 & 200 & 8 & 7181 & 6931 & 12207 & 11664 & 4069 & 3888 \\
\hline 6 & 200 & 6 & 1383 & 1328 & 5619 & 5458 & 1873 & 1819 \\
\hline
\end{tabular}

\subsection{Comparison between ANSYS17 and Experimental meth-} ods

Numerical model using ANSYS package were employed and compared with the experimental results. Tables (4-5) show the numerical results of critical buckling under dynamic increasing load without factor of safety (F.S). If a factor of safety of (2) may be taken. The table below gives the percentage discrepancy between the experimental and numerical results. The difference might be attributed to the fact that, due to the assumption made in the ANSYS package 1and the difficulties to control the measurement in the experimental work and some error may occur in reading the experimental data.

Table 3-5. Comparison between ANSYS results with experimental critical load value for long columns

\begin{tabular}{|c|c|c|c|c|c|c|c|c|}
\hline \multirow[t]{2}{*}{$\begin{array}{l}\text { Sp } \\
\text { No }\end{array}$} & \multirow{2}{*}{$\begin{array}{l}\mathbf{L} \\
\mathrm{mm}\end{array}$} & \multirow{2}{*}{$\begin{array}{l}\text { D } \\
\mathrm{mm}\end{array}$} & \multicolumn{2}{|c|}{$P_{\operatorname{EXP}}$} & \multicolumn{2}{|l|}{$\begin{array}{l}P_{\operatorname{cr}(\mathrm{N})} \\
A N S Y S\end{array}$} & \multicolumn{2}{|c|}{$\begin{array}{l}P_{\operatorname{cr}(\mathrm{N})} \\
A N S Y S \text { with S.F } \\
\text { of } 2\end{array}$} \\
\hline & & & $\begin{array}{l}\text { AS } \\
\text { received }\end{array}$ & $\begin{array}{l}60 \\
\text { days }\end{array}$ & $\begin{array}{l}\text { AS } \\
\text { received }\end{array}$ & $\begin{array}{l}60 \\
\text { days }\end{array}$ & $\begin{array}{l}\text { AS } \\
\text { received }\end{array}$ & $\begin{array}{l}60 \\
\text { days }\end{array}$ \\
\hline 1 & 400 & 8 & 1864 & 1787 & 3015 & 2914 & 1507 & 1457 \\
\hline 2 & 400 & 6 & 361 & 342 & 602 & 580 & 301 & 280 \\
\hline 3 & 400 & 4 & 114 & 110 & 187 & 181 & 93.5 & 90.5 \\
\hline 4 & 300 & 6 & 658 & 618 & 1066 & 1031 & 533 & 515.5 \\
\hline 5 & 300 & 4 & 211 & 202 & 333 & 322 & 166.5 & 161 \\
\hline 6 & 200 & 4 & 458 & 443 & 750 & 725 & 375 & 362 \\
\hline
\end{tabular}




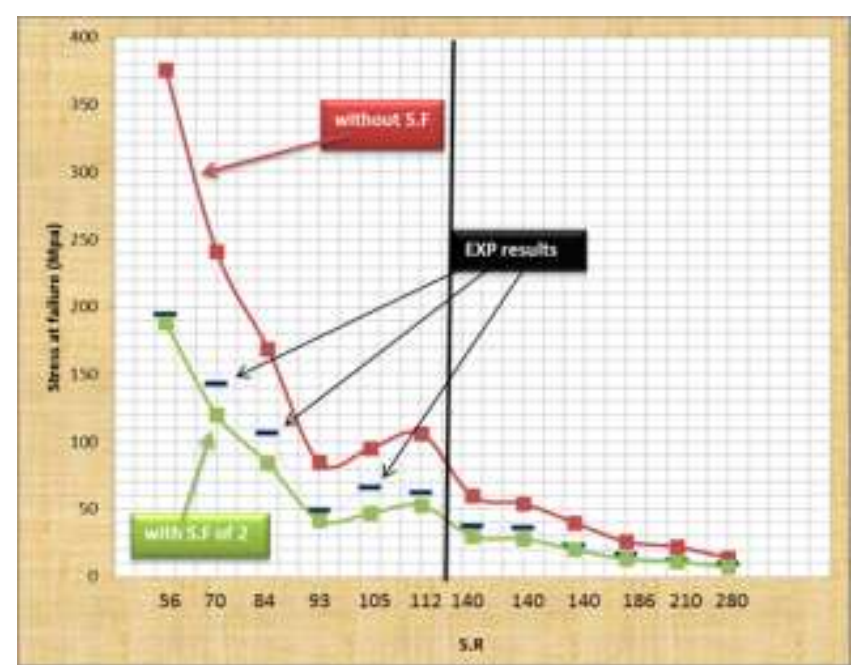

Figure 3-2:. ANSYS curve with the experimental results for 304 stainless steel alloy

\section{Conclusions}

1- The alarm laser system can be worked to control the critical load of buckling the assessment the failure of buckling which was equal to $1 \%$ of effective length.

2- The Perry-Robertson formula gives an approximation of the experimental results but with a safety factor of (1.3) that gives more satisfied expectations.

3- Corrosion leads to minimize the mechanical properties. The corroded specimens for two months have approximately $2.53 \%$ reduction in ultimate tensile strength comparing with noncorroded specimens.

4- The experimental results of this work is comfortable with Euler equation and Jonson with safety factors which gives an accuracy results

5- ANSYS 17 program used in calculating the buckling stresses showed good agreement in comparison with the analytical and experimental results, at safety factor (2).

\section{References}

[1] Allan L. F., Kasper S. L., "Methods for Decreasing the Total Solution Time of Linear Buckling Finite Element Analyses", M.Sc. Thesis, Aalborg University, Department of Mechanical and Manufacturing Engineering, (2012).

[2] Shruti D., "Buckling and Post Buckling of Structural Components", M.Sc. Thesis, University of Texas At Arlington, (2010).

[3] Amir Javidinejad, Zodiac Aerospace, "Buckling of Beams and Columns under Combined Axial and Horizontal Loading with Various Axial Loading Application Location", Journal of Theoretical and Applied Mechanics, Vol. 42, No. 4, 2012, pp. 19-30.

[4] Gazizov R., Nagovitsyna T. A., Political manipulation of The Media (on the example of mass media of the republic of Tatarstan, Astra Salvensis - review of history and culture, No. 10, 2017, p. 11-16.

[5] Husnutdinov D. H., Aydarova S. H., Sagdieva R. K., Mirzagitov R. H., Tsaran A., Plotnikova H., Velikanova S. Information and Communication Tools for Tatar Language teaching, Astra Salvensis, Supplement No. 2, 2017, p. 15.

[6] Adhithya Plato Sidharth, "Effect of pitting corrosion on ultimate strength and buckling strength of plate - A review ", Digest Journal of Nanomaterials and Biostructures. Vol. 4, No. 4, 2009, pp. 783 788.

[7] KatalinOszvald and LászlóDunai, "Effect of corrosion on the buckling of steel angle members - experimental study",periodica polytechnic, Vol. 56, No. 2, 2012, pp.175-183.
[8] Mohammad M. Kashani, Laura N. Lowes, Adam J. Crewe, and Nicholas A, 2016.

[9] "Stainless Steel Bridge in Bilbao". Outokumpu. "Stainless steel bridge". Archived from the original on 22 January 2013.

[10] Adhithya Plato Sidharth, "Effect of pitting corrosion on ultimate strength and buckling strength of plate - A review ", Digest Journal of Nanomaterials and Biostructures. Vol. 4, No. 4, 2009, pp. 783 788.

[11] KatalinOszvald and LászlóDunai, "Effect of corrosion on the buckling of steel angle members - experimental study", periodica polytechnic, Vol. 56, No. 2, 2012, pp.175-183.

[12] Mohammad M. Kashani, Laura N. Lowes, Adam J. Crewe, and Nicholas A, 2016 